ISSN (Print) : :1412-7601

ISSN (Online) : 2654-8712

Volume 7, No.1 Maret 2021

EKONOBIS

http://www.ekonobis.unram.ac.id

\title{
Pengaruh Belanja Modal, Investasi PMDN Dan Investasi PMA Terhadap Pertumbuhan Ekonomi Kabupaten/Kota Di Provinsi NTB
}

\section{Surtika Yanti, Luluk Fadliyanti, Abdul Manan}

Universitas Mataram

\begin{tabular}{l}
\hline A RTICLE INFO \\
Keywords: \\
Economic growth, capital \\
expenditure, domestic \\
investment, foreign \\
investment.
\end{tabular}

Kata Kunci :

Pertumbuhan ekonomi,

belanja modal,

penanaman modal dalam

negeri, penanaman modal asing.
ABSTRACT : This study aims to:1) Analize the influence of regional government capital expenditure, domestic investment, and foreign investment in the partial against the economic growth of regency/cities in West Nusa Tenggara province. 2) Analize the influence of regional government capital expenditure, domestic investment, and foreign investment is simultaneously against the economic growth of regency/cities in West Nusa Tenggara province. The data were secondary data from ten residences/cities in West Nusa Tenggara province in the period 2014-2018 obtained from the Central Statistics Agency in West Nusa Tenggara province, Regional Financial and Asset Management Agency in West Nusa Tenggara province, and The One Stop Investment and Integrated Services Office in West Nusa Tenggara province. The data were panel data analysis using the fixed effect regression model processed by eviews 9. The results of the study showed that:1) In The partial, regional government capital expenditure and foreign investment had a significant effect on the economic growth of residences/cities in West Nusa Tenggara province, while domestic investment had a insignificant effect on the economic growth of residences/cities in West Nusa Tenggara province. 2) Is Simultaneously regional government capital expenditure, domestic investment, and foreign investment had a significant effect on the economic growth of residences/cities in West Nusa Tenggara province.

ABSTRAK: Penelitian ini bertujuan untuk: 1) Menganalisis pengaruh Belanja Modal
Pemerintah Daerah, Penanaman Modal Dalam Negeri, dan Penanaman Modal Asing secara parsial terhadap pertumbuhan ekonomi kabupaten/kota di Provinsi Nusa Tenggara Barat. 2) Menganalisis pengaruh belanja modal pemerintah daerah, penanaman modal dalam negeri, dan penanaman modal asing secara simultan terhadap pertumbuhan ekonomi kabupaten/kota di Provinsi Nusa Tenggara Barat. Data tersebut merupakan data sekunder dari sepuluh kabupaten/kota di Provinsi Nusa Tenggara Barat periode 2014-2018 yang diperoleh dari Badan Pusat Statistik Provinsi Nusa Tenggara Barat, Badan Pengelola Aset dan Keuangan Daerah Provinsi Nusa Tenggara Barat, dan The One Stop Investment, dan Kantor Pelayanan Terpadu Provinsi Nusa Tenggara Barat. Data yang diperoleh adalah analisis data panel menggunakan model regresi fixed effect yang diolah dengan eviews 9. Hasil penelitian menunjukkan bahwa: 1) Secara parsial, belanja modal pemerintah daerah dan investasi asing berpengaruh signifikan terhadap pertumbuhan ekonomi pemukiman/kota di Provinsi Nusa Tenggara Barat, sedangkan PMDN berpengaruh tidak signifikan terhadap pertumbuhan ekonomi. Kabupaten/Kota di Provinsi Nusa Tenggara Barat. 2) Apakah secara simultan Belanja Modal Pemerintah Daerah, Penanaman Modal Dalam Negeri, dan Penanaman Modal Asing berpengaruh signifikan terhadap pertumbuhan ekonomi kabupaten/kota di Provinsi Nusa Tenggara Barat.

Corresponding Author:

Alamat : Program Studi Ekonomi Pembangunan, Fakultas Ekonomi dan Bisnis, Universitas Mataram, Jln. Majapahit No. 62 Mataram.

e-mail: lulukfadliyanti@unram.ac.id 


\section{PENDAHULUAN}

Latar Belakang

Pembangunan ekonomi merupakan serangkaian usaha dan kebijakan yang dilakukan untuk meningkatkan taraf hidup masyarakat, memperluas lapangan kerja, memeratakan pendapatan masyarakat, meningkatkan hubungan regional dan menggeser kegiatan ekonomi dari sektor primer ke sektor sekunder dan tersier. Dengan kata lain, arah dari pembangunan ekonomi adalah mengusahakan agar pendapatan masyarakat meningkat dan dengan tingkat pemerataan yang sebaik mungkin. Pembangunan ekonomi akan mendorong pertumbuhan ekonomi, dan sebaliknya pertumbuhan ekonomi akan memperlancar proses pembangunan ekonomi (Daniar, 2016).

Teori pertumbuhan ekonomi neo klasik menyatakan pertumbuhan ekonomi bergantung pada perkembangan faktorfaktor produksi, yaitu modal, tenaga kerja, dan teknologi (Sukirno, 1994 dalam Rustiono, 2008). Peningkatan modal berupa modal fisik seperti infrastruktur serta sarana prasarana oleh pemerintah dengan pengoptimalan belanja modal sebagai investasi, peningkatan jumlah tenaga kerja serta dukungan dengan kemajuan teknologi yang semakin canggih maka akan meningkatkan output yang dihasilkan. Sejak diberlakukannya kebijakan otonomi daerah pada januari 2001, setiap daerah memiliki kewenangan untuk membuat kebijakan dibidang keuangan dan pengelolaan baik anggaran di sisi penerimaan maupun pengeluaran. Desentralisasi pada sisi pendapatan dan pengeluaran dipandang sebagai cara untuk meningkatkan efisiensi sektor publik, memotong defisit anggaran, dan meningkatkan pertumbuhan ekonomi. Hal ini dikarenakan pemerintah daerah memiliki posisi yang lebih baik daripada pemerintah nasional dalam menyampaikan layanan publik sesuai dengan preferensi dan kebutuhan lokal yang efisien dan akan mengakibatkan pertumbuhan ekonomi yang lebih cepat baik lokal maupun nasional (Zhang and Zou, 1998).

Undang-Undang No. 23 Tahun 2014 tentang pemerintah daerah dan UndangUndang No. 33 Tahun 2004 tentang perimbangan keuangan antara pemerintah pusat dan daerah merupakan wujud pelaksanaan otonomi daerah dimana harus diimbangi dengan kemampuan daerah mengoptimalkan pengelolaan keuangan yang lebih adil, proporsional, demokratis, transparan dan bertanggung jawab dalam rangka pendanaan 
penyelenggaraan desentralisasi, dengan mempertimbangkan potensi, kondisi dan kebutuhan daerah serta besaran pendanaan penyelenggaraan dekonsentrasi dan tugas-tugas pembantuan. Tidak hanya pihak swasta yang berupaya dalam melakukan penanaman modal tetapi pemerintah juga ikut berperan. Misalnya saja pemerintah melakukan perbaikan infrastruktur dan melakukan penambahan aset. Pembiayaan pembangunan daerah untuk infrastruktur ini biasanya disebut dengan belanja modal. Belanja modal merupakan pengeluaran yang berkaitan dengan kegiatan investasi yang dilaksanakan oleh pemerintah untuk mencapai sasaran pembangunan. Belanja modal akan menghasilkan penyediaan sarana dan prasarana yang dibutuhkan untuk meningkatkan pertumbuhan ekonomi.

Provinsi NTB merupakan daerah dengan daya tarik di bidang investasi, infrastruktur, layanan publik, dan pariwisata. Hal ini terbukti dengan NTB meraih penghargaan Indonesia's Attractiveness Award 2019. Terpilihnya provinsi NTB sebagai pemenang Indonesia's Attractiveness Award 2019 menunjukkan adanya potensi besar provinsi NTB untuk dapat menarik minat investor berbagai industri dan pelaku bisnis beragam sektor untuk turut memajukan perekonomian daerah.

Pemerintah daerah dalam upaya memenuhi kewajiban daerah salah satu tujuannya adalah meningkatkan perekonomian yang diharapkan akan berdampak secara langsung terhadap peningkatan kualitas hidup masyarakat. Pengeluaran pemerintah dalam APBD yang digunakan untuk dapat menciptakan pertumbuhan ekonomi tercermin dalam belanja modal. Disebabkan karena belanja modal digunakan oleh pemerintah untuk melakukan investasi diberbagai bidang. Sari, dkk (2015:7) menyatakan bahwa untuk menstimulus pertumbuhan ekonomi diperlukan aset tetap seperti infrastruktur serta sarana prasarana yang dapat menunjang kegiatan perekonomian. Pembangunan aset tetap didanai dari pengalokasian anggaran belanja modal. Penanaman modal merupakan langkah awal untuk melakukan pembangunan. Penanaman modal yang berasal dari dalam negeri yang disebut Penanaman Modal Dalam Negeri (PMDN) dan penanaman modal yang berasal dari luar negeri yang disebut Penanaman Modal Asing (PMA). Keduanya sama penting dan berpengaruh terhadap pertumbuhan ekonomi suatu negara (Dumairy, 1996). Peran belanja modal dan investasi di Provinsi NTB selama 
5 tahun terakhir belum terlihat dalam mendukung pertumbuhan ekonomi dengan laju pertumbuhan ekonomi ratarata sebesar $5.62 \%$ per tahun. Rata-rata laju pertumbuhan ekonomi terbesar adalah pada Kabupaten Sumbawa Barat yaitu sebesar $12.32 \%$ per tahun, sedangkan, rata-rata pertumbuhan ekonomi terendah di Kabupaten Lombok Utara yaitu $3.96 \%$ per tahun. Dimana belanja modal dan investasi menunjukkan peningkatan yang cukup tinggi tetapi belum bisa mendorong pertumbuhan ekonomi yang tinggi pula. Fakta ini memberikan informasi yang menarik, apakah investasi berpengaruh positif terhadap pertumbuhan ekonomi kabupaten/kota di Provinsi NTB.

\section{Rumusan Masalah}

Berdasarkan uraian latar belakang di atas, maka rumusan masalah dalam penelitian ini adalah :

1. Bagaimana pengaruh belanja modal pemerintah daerah, investasi PMDN dan investasi PMA secara parsial terhadap pertumbuhan ekonomi kabupaten/kota di Provinsi NTB ?

2. Bagaimana pengaruh belanja modal pemerintah daerah, investasi PMDN dan investasi PMA secara simultan terhadap pertumbuhan ekonomi kabupaten/kota di Provinsi NTB ?

\section{TINJAUAN PUSTAKA}

Rahardja dan Manurung (2008) suatu perekonomian akan dikatakan mengalami pertumbuhan ekonomi jika jumlah produksi barang dan jasanya meningkat. Sangat sulit mencatat jumlah unit barang dan jasa yang dihasilkan selama periode tertentu dikarenakan jenis barang dan jasa yang dihasilkan sangat beragam dan dengan satuan ukuran yang berbeda. Oleh karena itu, angka yang digunakan untuk menaksir perubahan output adalah nilai moneternya (uang) yang tercermin dalam nilai Produk Domestik Bruto (PDB). Pembentukan pertumbuhan ekonomi tidak lepas dari proses pembangunan ekonomi. Pembangunan ekonomi mendorong pertumbuhan ekonomi, sebaliknya pertumbhan ekonomi memperlancar proses pembangunan ekonomi. Adanya pertumbuhan ekonomi merupakan indikasi keberhasilan pembangunan ekonomi. Adisasmita (2014) pertumbuhan ekonomi (economic growth) dimaksudkan sebagai kegiatan peningkatan kapasitas produksi yang tersedia yang terdiri dari lahan (sumberdaya alam), sumberdaya manusia (penduduk), sumberdaya modal, sumberdaya teknologi dan sumberdaya pembangunan lainnya. 
Adapun untuk menghitung tingkat petumbuhan ekonomi digunakan indikator tingkat pertumbuhan angka-angka pendapatan nasional, seperti Produk Domestik Bruto (PDB) atau Produk Nasional Bruto (PNB). Dalam praktek, angka PDB lebih lazim digunakan kerimbang PNB mengingat batas wilayah perhitungan PDB terbatas pada negara yang bersangkutan (domestik), karena dengan demikian kebijakan-kebijakan ekonomi yang diterapkan pemerintah untuk mendorong aktivitas perekonomian domestik bisa dinilai efektivitasnya (Syahrani, 2011).

Pengeluaran pemerintah yang merupakan bagian dari perhitungan pertumbuhan ekonomi dapat dinilai dari berbagai segi, sehingga dapat dibedakan menjadi : (1) pengeluaran merupakan investasi yang menambah kekuatan dan ketahanan ekonomi dimasa-masa yang akan datang, (2) pengeluaran itu langsung memberikan kesejahteraan dan kegembiraan bagi masyarakat, (3) merupakan penghematan pengeluaran yang akan datang, dan (4) menyediakan kesempatan kerja lebih banyak dan menciptakan pasar yang lebih luas (Suparmoko, 2000). Dan Investasi atau penanaman modal merupakan istilahistilah yang dikenal, baik dalam kegiatan bisnis sehari-hari maupun dalam bahasa perundang-undangan. Istilah investasi merupakan istilah yang lebih popular dalam dunia usaha, sedangkan istilah penanaman modal lebih banyak digunakan dalam bahasa perundang-undangan. Namun, pada dasarnya kedua istilah tersebut mempunyai pengertian yang sama sehingga kadang-kadang digunakan secara interchangeable (Supanca, 2006).

Sukirno (2002) investasi dapat diartikan sebagai pengeluaran atau pembelanjaan penanaman modal atau perusahaan untuk membeli barang-barang modal dan perlengkapan-perlengkapan produksi untuk menambah kemampuan produksi barang-barang dan jasa-jasa yang tersedia dalam perekonomian. Besar kecilnya investasi dalam kegiatan ekonomi ditentukan oleh tingkat suku bunga, tingkat pendapatan, kemajuan teknologi, ramalan kondisi ekonomi kedepan dan faktor-faktor lainnya. Mankiw (2003) berpendapat bahwa investasi terdiri dari barang-barang yang di beli untuk penggunaan di masa depan. Salah satu kegiatan investasi yang dapat diketahui adalah penanaman modal, penanaman modal dapat dilakukan baik oleh pemerintah maupun swasta. Untuk investasi swasta di Indonesia yang dilakukan dengan kemudahan fasilitas berupa PMA dan PMDN. 
Penanaman modal dalam negeri sebagai sumber domestik menjadi salah satu kunci utama untuk mendorong pertumbuhan ekonomi. Disatu pihak mencerminkan permintaan efektif, di lain pihak dapat menciptakan efisiensi produktif bagi produksi dimasa depan. Proses penanaman modal ini menghasilkan output nasional dalam berbagai cara. Investasi dibidang barang modal tidak hanya meningkatkan produksi tetapi juga meningkatkan penggunaan tenaga kerja. Penanaman modal ini juga akan membawa dampak yang positif, salah satu contohnya adalah penanaman modal ini akan membawa kearah spesialisasi dan penghematan produksi secara luas (Fuad, 2018). Penanaman Modal di Indonesia diatur dengan Undang-Undang Nomor 25 tahun 2007 tentang Penanaman Modal. Dalam Undang-Undang ini yang dimaksud dengan Penanaman Modal Asing adalah kegiatan menanam modal untuk melakukan usaha di wilayah Republik Indonesia yang dilakukan oleh penanam modal asing, baik menggunakan modal asing sepenuhnya maupun yang berpatungan dengan penanam modal dalam negeri (Pasal 1 Undang-Undang Nomor 25 tahun 2007 tentang Penanaman Modal). Menurut Salim dan Budi (2008), penanaman modal asing merupakan transfer modal baik nyata maupun tidak nyata dari suatu negara ke negara lain atau pemindahan modal. Tujuan pemindahan modal ini digunakan di negara tersebut agar menghasilkan keuntungan dibawah pengawasan dari pemilik modal, baik total maupun sebagian.

Arsyad (2010) menyebutkan bahwa manfaat investasi asing atau penanaman modal asing bagi negara sedang berkembang, antara lain untuk menciptakan lapangan kerja; proses ahli teknologi dan ketrampilan yang bermanfaat; dan menjadi sumber tabungan atau devisa. Degan adanya penanaman modal asing dapat menciptakan lapanan kerja sehingga dapat menggurangi pengangguran, selain itu dengan adanya investasi asing akan mendapatkan ketrampilan baru bagi negara sedang berkembang. Penanaman modal asing juga merupakan sumber tabungan kerena dengan adanya investor asing yang menanamkan modalnya maka pertumbuhan ekonomi akan meningkat.

Sari, dkk (2015) menyatakan bahwa untuk menstimulus pertumbuhan ekonomi diperlukan aset tetap seperti infrastruktur serta sarana prasarana yang dapat menunjang kegiatan perekonomian. Pembangunan aset tetap didanai dari pengalokasian anggaran belanja modal. 
Apabila pertumbuhan ekonomi suatu daerah semakin meningkat, maka pemerintah daerah akan meningkatkan belanja modalnya untuk memperbaiki dan melengkapi infrastruktur dan sarana prasarana dengan tujuan untuk mencapai pertumbuhan ekonomi yang lebih baik. Kekuatan ekonomi utama yang menentukan investasi adalah hasil biaya investasi yang ditentukan oleh kebijakan tingkat bunga dan pajak, serta harapan mengenai masa depan (Samuelson dan Nordhaus, 1993). Investasi PMA dapat dimanfaatkan oleh negara berkembang dalam memacu kenaikan pertumbuhan ekonomi, untuk menjaga dan mempertahankan tingkat pertumbuhan yang lebih tinggi dengan perubahan dan perombakan yang substansial dalam struktur produksi dan dalam mobilisasi sumber dana transformal struktural.

\section{METODE PENELITIAN}

Jenis penelitian yang dilakukan dalam penelitian ini adalah penelitian deskriptif kuantitatif. Penelitian deskriptif adalah penelitian yang meneliti suatu kelompok manusia, suatu objek, suatu set kondisi, suatu sistem pemikiran ataupun suatu kelas peristiwa pada masa sekarang dengan tujuan untuk membuat suatu gambaran atau lukisan secara sistematis dan factual serta akurat mengenai faktafakta, sifat-sifat dan hubungan antar fenomena-fenomena yang diselidiki (Nasir, 2011). Lokasi penelitian dilaksanakan di provinsi NTB yang terdiri dari 8 kabupaten dan 2 kotamadya, dengan 17 kecamatan dan 1.143 desa. Selama tahun 2018 terjadi pemekaran pada level kecamatan dan desa. Untuk mengetahui bagaimana pengaruh dari belanja modal, investasi PMDN, dan investasi PMA terhadap pertumbuhan ekonomi, maka digunakan alat analisis statistik yaitu regresi data panel. Sebelum melakukan uji regresi maka terlebih dahulu dilakukan uji chou, uji hausman, dan uji lagrange multiplier yang mana pengujian ini adalah pengujian statistik untuk memilih apakah model common effect, fixed effect atau random effect yang paling tepat digunakan. Dalam penelitian ini tidak dilakukan uji asumsi klasik karena salah satu kelebihan menggunakan data panel adalah data yang digunakan menjadi lebih informative, variabilitasnya lebih besar, kolinearitas yang lebih rendah diantara variabel dan banyak derajat serta lebih efisien (Hariayanto, 2005). Panel data memungkinkan mempelajari lebih kompleks mengenai perilaku yang ada dalam model sehingga pengujian data 
panel tidak memerlukan uji asumsi klasik (Gujarati, 1992).

Analisis regresi bertujuan untuk mengetahui pengaruh dari variabel bebas terhadap variabel terikat. Sehingga, untuk mengetahui pengaruh dari belanja modal pemerintah daerah, investasi PMDN, dan investasi PMA terhadap pertumbuhan ekonomi maka digunakan analisis regresi data panel dengan formulasi sebagai berikut:

Yit $=\beta 0 i t+\beta 1 X 1 i t+\beta 2 \times 2 i t+\beta 3 X 3 i t+e i t$

Keterangan:

$\mathrm{Y}=$ Pertumbuhan Ekonomi

ßO = Konstanta

X1 = Belanja Modal

X2 = Investasi PMDN

X3 = Investasi PMA

$\beta=$ Koefisien regresi

$\mathrm{e}=$ Error term

$\mathrm{t}=$ Waktu

$\mathrm{i}=$ Kabupaten $/$ kota

Dalam metode estimasi model regresi dengan menggunakan data panel dapat dilakukan melalui tiga pendekatan, antara lain (Widarjono, 2009):

\section{Common Effect Model}

Merupakan pendekatan model data panel yang paling sederhana karena hanya mengkombinasikan data time series dan cross section. Pada model ini tidak diperhatikan dimensi waktu maupun individu, sehingga diasumsikan bahwa perilaku data perusahaan sama dalam berbagai kurun waktu. Metode ini bisa menggunakan pendekatan Ordinary Least Square (OLS) atau teknik kuadrat terkecil untuk mengestimasi model data panel.

\section{Fixed Effect Model}

Model ini mengasumsikan bahwa perbedaan antar individu dapat diakomodasi dan perbedaan intersepnya. Untuk mengestimasi data panel model Fixed Effects menggunakan teknik variable dummy untuk menangkap perbedaan intersep antar perusahaan, perbedaan intersep bisa terjadi karena perbedaan budaya kerja, manajerial, dan insentif. Namun demikian slopnya sama antar perusahaan. Model estimasi ini sering juga disebut dengan teknik Least Squares Dummy Variable (LSDV).

\section{Random Effect Model}

Model ini akan mengestimasi data panel dimana variabel gangguan mungkin saling berhubungan antar waktu dan antar individu. Pada model random effect perbedaan intersip diakomodasi oleh error term masing-masing perusahaan. Keuntungan menggunkan model random effect yakni menghilangkan heteroskedastisitas. Model ini juga disebut dengan Error Component Model (ECM) 
atau teknik Generalized Least Square (GLS).

Untuk memilih model yang paling tepat digunakan terdapat beberapa pengujian yang dapat dilakukan, antara lain :

1.Uji Chow

Chow test merupakan uji untuk membandingkan model Common Effect atau Fixed Effect (Widarjono, 2009). Hipotesis yang dibentuk dalam Chow test adalah :

HO : Common Effect

$\mathrm{H} 1$ : Fixed Effect

H0 diterima jika P-value $>0.05$. Sebaliknya, HO ditolak jika P-value $<0.05$. Tingkat signifikansi yang digunakan sebesar $5 \%$.

2.Uji Hausman

Hausman test adalah pengujian statistik untuk membandingkan model Fixed Effect dengan Random Effect dalam menentukan model yang terbaik untuk digunakan sebagai model regresi data panel (Gujarati, 2012). Hipotesis yang dibentuk dalam Hausman test adalah :

HO : Random Effect

H1 : Fixed Effect

HO diterima jika P-value $>0.05$. Sebaliknya, HO ditolak jika P-value $<0.05$. Tingkat signifikansi yang digunakan sebesar $5 \%$.

3.Uji Lagrange Multiplier

Lagrange Multiplier test adalah pengujian statistik untuk menguji model apakah model Random Effect atau Common Effect (OLS) yang lebih tepat digunakan (Basuki dan Prawoto, 2016:282).

$$
\begin{aligned}
& \mathrm{HO}: \mathrm{PLS} \text { (CE) } \\
& \mathrm{H} 1: \mathrm{RE}
\end{aligned}
$$

HO diterima jika P-value $>0.05$. Sebaliknya, HO ditolak jika P-value $<0.05$. Tingkat signifikansi yang digunakan sebesar $5 \%$.

Untuk uji kriteria statistic digunakan:

1.Uji Parsial (Uji t)

Uji t merupakan pengjian variabel-variabel independen secara individu (parsial), dengan tujuan untuk mengetahui seberapa jauh pengaruh masing-masing variabel independen dalam mempengaruhi variabel dependen, dengan anggapan variabel lain dianggap konstan (tetap). Hipotesis dalam pengujian t-stistic adalah :

Ho : $\beta 1, ß 2, ß 3=0$ (diduga belanja modal, investasi PMDN, dan investasi PMA secara parsial tidak berpengaruh signifikan terhadap pertumbuhan ekonomi kabupaten/kota di provinsi NTB tahun 2014-2018)

$\mathrm{Ha}: ß 1, ß 2, ß 3 \neq 0$ (diduga belanja modal, investasi PMDN, dan investasi PMA secara parsial berpengaruh signifikan terhadap pertumbuhan ekonomi kabupaten/kota di provinsi NTB tahun 2014-2018).

Jika Sig $<0,05$ atau thitung $>$ ttabel maka Ha diterima atau Ho ditolak, sebaliknya jika 
Sig $>0,05$ atau thitung < ttabel maka $\mathrm{Ha}$ ditolak atau Ho diterima. Tingkat signifikansi yang digunakan dalam pengujian ini sebesar 5\%. Pengujian tstatistic juga dapat dilakukan dengan membandingkan nilai t-statistic dengan nilai t menurut tabel (Widarjono, 2009).

2.Uji Simultan (Uji F)

Uji F menunjukkan apakah semua variabel independen dalam model mempunyai pengaruh secara bersama-sama terhadap variabel dependen (Kuncoro, 2011). Pengujian ini dilakukan dengan tingkat signifikansi 5\%. Hipotesis dalam pengujian F-Statistic adalah :

Ho : $\beta 1, ß 2, ß 3=0$ (diduga belanja modal, investasi PMDN, dan investasi PMA secara simultan tidak berpengaruh signifikan terhadap pertumbuhan ekonomi kabupaten/kota di provinsi NTB tahun 2014-2018).

Ha : ß1, ß2, ß3 $\neq 0$ (diduga belanja modal, investasi PMDN, dan investasi PMA secara simultan berpengaruh signifikan terhadap pertumbuhan ekonomi kabupaten/kota di provinsi NTB tahun 2014-2018).

Jika Sig $<0,05$ atau Fhitung $>$ Ftabel maka Ha diterima atau Ho ditolak, sebaliknya jika Sig $>0,05$ atau Fhitung < Ftabel maka $\mathrm{Ha}$ ditolak atau Ho diterima. Pengujian Fstatistic juga dapat dilakukan dengan membandingkan nilai F-statistic dengan nilai F menurut tabel.

\section{HASIL DAN PEMBAHASAN}

Dalam menentukan model estimasi yang dapat digunakan untuk penelitian ini dilakukan beberapa pengujian yaitu uji chow, uji hausman, dan uji lagrange multiplier.

\section{Uji Chow}

Untuk mengetahui model panel yang akan digunakan, maka digunakan uji FRestricted dengan cara melihat nilai probabilitas (P-Value) F-Statistik lebih kecil dari tingkat signifikansi $\alpha=5 \%$. Sebelum melihat nilai probabilitas (P-Value) FStatistik lebih kecil dari tingkat signifikansi $\alpha=5 \%$, terlebih dahulu dibuat hipotesisnya. Adapun hipotesisnya adalah sebagai berikut:

HO : Common Effect Model

H1 : Fixed Effect Model

Dari hasil berdasarkan metode Fixed Effect Model (FEM) dan Common Effect Model (CEM) diperoleh nilai probabilitas Fstatistik yakni sebagai berikut:

Tabel 1 Hasil Uji Chow

\begin{tabular}{|c|c|c|c|}
\hline Effects Test & Statistic & d.f & Prob. \\
\hline Cross-section F & 17.0748 & $(9,37)$ & 0.0000 \\
\hline Cross-section Chi-square & 81.9822 & 9 & 0.0000 \\
\hline
\end{tabular}

Sumber: data diolah

Berdasarkan tabel 1 di atas diperoleh Fstatistik adalah 17.07483 dengan d.f $(9,37)$ 
dan nilai probability F-Statistik sebesar 0.0000 , yang berarti bahwa nilai probability F-Statistik lebih kecil dari tingkat signifikansi $\alpha 5 \%(0.0000<0.05)$. Maka Ho ditolak, sehingga model panel yang digunakan adalah Fixed Effect Model.

\section{Uji Hausman}

Setelah melakukan pengujian untuk model CEM dan FEM, agar diketahui model panel yang akan diterapkan, selanjutnya dilakukan uji Hausman, pengujian ini untuk menentukan model paling tepat yang akan digunakan diantara FEM dan REM. Uji Hausman memberikan penilaian dengan menggunakan Chi-Square Statistic sehingga keputusan pemilihan model dapat ditentukan dengan tepat. Sebelum membandingkan Chi-square statistic dan Chi-square table terlebih dahulu dibuat hipotesisnya adalah sebagai berikut:

HO : Random Effect Model

H1 : Fixed Effect Model

Hasil pengolahan dengan uji Hausman dapat dilihat pada tabel 4.4 berikut:

Tabel 2 Hasil Uji Hausman

\begin{tabular}{|c|c|r|c|}
\hline Test Summary & \multicolumn{1}{|c|}{$\begin{array}{c}\text { Chi-Sq. } \\
\text { Statistic }\end{array}$} & $\begin{array}{c}\text { Chi- } \\
\text { Sq.d.f }\end{array}$ & Prob. \\
\hline Cross-section random & 102.01115 & 3 & 0.0000 \\
\hline
\end{tabular}

Sumber: data diolah

Berdasarkan hasil uji Hausman pada tabel

2 di atas, didapatkan Chi-Square statistic sebesar 102.01115 dengan probability 0.0000 dan d.f. 3. Dikarenakan nilai probability Chi-Square statistic lebih kecil dari nilai $\alpha 5 \%(0.0000<0.05)$ maka Ho ditolak. Dapat disimpulkan bahwa model terbaik yang dapat digunakan untuk model penelitian adalah Fixed Effect Model. Jadi, berdasarkan uji Chow dan uji Hausman model yang paling tepat digunakan adalah Fixed Effect Model sehingga untuk uji lagrange multiplier tidak perlu dilakukan pengujian. Berikut ini tabel 3 yang menunjukkan hasil estimasi regresi menggunakan Fixed Effect Model.

Tabel 3 Hasil Estimasi Regresi Fixed Effect Model

\begin{tabular}{|c|r|r|c|}
\hline Variable & Coefficient & t-Statistic & Prob. \\
\hline C & $4.51 \mathrm{E}+09$ & 4.999110 & 0.0000 \\
\hline $\mathrm{X} 1$ & 0.010881 & 3.380040 & 0.0017 \\
\hline $\mathrm{X} 2$ & 0.000523 & 1.943958 & 0.0595 \\
\hline $\mathrm{X} 2$ & 0.001903 & 5.680269 & 0.0000 \\
\hline F-s ta tistic & 53.5673 & 0.00000 \\
\hline \multicolumn{3}{|c|}{$\mathrm{R}^{2}$} & 0.945573 \\
\hline Adjusted $\mathrm{R}^{2}$ & 0.927921 \\
\hline
\end{tabular}

Sumber: data diolah

Adapun uji kriteria statistic dilakukan untuk menguji apakah variabel independen (belanja modal, investasi PMDN, dan investasi PMA) berpengaruh secara parsial terhadap variabel dependennya Pertumbuhan Ekonomi NTB, yaitu dengan membandingkan masingmasing nilai t-statistik dari regresi dengan t-tabel dalam menolak atau menerima hipotesis. Pada tingkat keyakinan $\alpha=5 \%$ 
dengan jumlah observasi sebanyak 50 .

Hasil uji t sebagai berikut :

Tabel 4 Hasil Uji t

\begin{tabular}{|c|c|c|c|l|}
\hline Variable & Coefficient & $\begin{array}{c}\mathrm{t}- \\
\text { Statistic }\end{array}$ & Prob. & \multicolumn{1}{|c|}{ Sig. } \\
\hline $\mathrm{X} 1$ & 0.010881 & 3.380040 & 0.0017 & Signifikan \\
\hline $\mathrm{X} 2$ & 0.000523 & 1.943958 & 0.0595 & Tidak Signifikan \\
\hline $\mathrm{X} 2$ & 0.001903 & 5.680269 & 0.0000 & Signifikan \\
\hline
\end{tabular}

Sumber: data diolah

Tabel 4 adalah tabel hasil pengujian variabel independen yaitu belanja modal, investasi PMDN, dan investasi PMA terhadap Pertumbuhan Ekonomi NTB secara parsial. Adapun hipotesisnya sebagai berikut :

a. Diduga belanja modal berpengaruh signifikan terhadap Pertumbuhan Ekonomi kabupaten/kota di provinsi NTB 2014-2018.

b. Diduga investasi PMDN berpengaruh signifikan terhadap Pertumbuhan Ekonomi kabupaten/kota di provinsi NTB 2014-2018

c. Diduga investasi PMA berpengaruh signifikan terhadap Pertumbuhan Ekonomi kabupaten/kota di provinsi NTB 2014-2018

Berdasarkan hasil regresi yang ada di tabel 4.6 maka pembuktian dari hipotesis yang telah dipaparkan adalah sebagai berikut :

a. Variabel belanja modal (X1) memiliki nilai probability yang lebih kecil dari tingkat keyakinan $\alpha=5 \%$ yakni $0.0017<0.05$ yang berarti membuktikan bahwa variabel belanja modal berpengaruh signifikan terhadap pertumbuhan ekonomi kabupaten/kota di provinsi NTB.

b. Variabel investasi PMDN (X2) memiliki nilai probability yang sedikit lebih besar dari tingkat keyakinan $\alpha=5 \%$ yakni $0.0595>$ 0.05 yang berarti membuktikan bahwa variabel investasi PMDN berpengaruh tidak signifikan terhadap pertumbuhan ekonomi kabupaten/kota di provinsi NTB.

c. Variabel investasi PMA (X3) memiliki nilai probability yang lebih kecil dari tingkat keyakinan $\alpha=5 \%$ yakni $0.0000<0.05$ yang berarti membuktikan bahwa variabel investasi PMA berpengaruh signifikan terhadap pertumbuhan ekonomi kabupaten/kota di provinsi NTB.

1.Uji F

Untuk menguji apakah variabel independen berpengaruh secara simultan (bersama-sama) terhadap variabel dependennya, maka digunakan uji-F dengan cara membandingkan F-statistik dengan F-tabel. Adapun hipotesisnya adalah sebagai berikut: 
Ho : Belanja modal, investasi PMDN, dan investasi PMA secara simultan tidak berpengaruh signifikan terhadap pertumbuhan ekonomi kabupaten/kota di provinsi NTB tahun 2014-2018.

Ha : Belanja modal, investasi PMDN, dan investasi PMA secara simultan berpengaruh signifikan terhadap pertumbuhan ekonomi kabupaten/kota di provinsi NTB tahun 2014-2018.

Tabel 5 Hasil Uji F

\begin{tabular}{|l|l|}
\hline F-statistic & 53.56730 \\
\hline Prob (F-statistic) & 0.000000 \\
\hline
\end{tabular}

Sumber: data diolah

Berdasarkan tabel 5 di atas, hasil regresi data panel menggunakan Fixed Effect Model diperoleh nilai F-statistik sebesar 53.56730 dengan probabilitas sebesar 0,00000 , pada tingkat keyakinan $\alpha=5 \%$, terlihat bahwa nilai probabilitas F-statistik lebih kecil dari tingkat signifikansi $\alpha$ 5\% $(0,0000<0,05)$, artinya bahwa variabel independen yakni belanja modal, investasi PMDN, dan investasi PMA secara bersamasama berpengaruh signifikan terhadap Pertumbuhan Ekonomi NTB tahun hitung 2014-2018

Berdasarkan hasil regresi data panel menggunakan Fixed Effect Model didapatkan koefisien determinasi sebesar 0.945573 atau 94,56\%. Hal ini menunjukkan bahwa sebesar 94,56\%
Pertumbuhan Ekonomi di Provinsi NTB dapat dijelaskan oleh variabel belanja modal, invetasi PMDN, dan investasi PMA. Sedangkan sisanya 5,44\% dijelaskan oleh variabel lain yang tidak diteliti dalam penelitian ini seperti teknologi dan tenaga kerja.

\section{Tabel 6 Hasil Uji Koefisien Determinasi}

\begin{tabular}{|l|l|}
\hline R-squared & 0.945573 \\
\hline Adjusted R-squared & 0.927921 \\
\hline
\end{tabular}

Sumber: data diolah

Setelah melalui Uji Chow dan Uji Hausman, ditetapkan bahwa model empiris data panel adalah dengan menggunakan Fixed Effect Model, dapat dijelaskan melalui persamaan sebagai berikut:

Yit $=4,509,356,249+0.010881 \times 1 i t+$ $0.000523 \times 2 i t+0.001903 \times 3 i t+$ eit

Keterangan:

$\mathrm{Y}=$ Pertumbuhan Ekonomi (PDRB)

X1 = Belanja Modal

$\mathrm{X} 2$ = Investasi PMDN

X3= Investasi PMA

e $=$ error term

$\mathrm{t}=$ Waktu

$\mathrm{i}=$ Kabupaten $/$ kota

Berdasarkan persamaan regresi diatas, dapat dilihat bahwa koefisien konstanta atau parameter sebesar 4,509,356,249 menunjukkan bahwa jika variabel belanja modal, investasi PMDN, dan investasi PMA dianggap konstan, maka pertumbuhan 
ekonomi yang diukur dengan nilai PDRB sebesar 4,509,356,249. Nilai koefisien regresi variabel belanja modal sebesar 0.010881, hal ini berarti setiap peningkatan belanja modal 1 rupiah, maka dapat menyebabkan kenaikan pertumbuhan ekonomi (PDRB) sebesar 0.010881 rupiah dengan asumsi variabel lain tetap. Pada variabel investasi PMDN diperoleh nilai koefisien regresi sebesar 0.000523 berarti bahwa setiap peningkatan variabel investasi PMDN sebesar 1 rupiah maka dapat menyebabkan kenaikan pertumbuhan ekonomi (PDRB) sebesar 0.000523 rupiah dengan asumsi variabel lain tetap. Nilai koefisien variabel investasi PMA sebesar 0.001903, hal ini berarti bahwa setiap peningkatan variabel investasi PMA sebesar 1 rupiah maka dapat menyebabkan kenaikan pertumbuhan ekonomi (PDRB) sebesar 0.001903 rupiah dengan asumsi variabel lain tetap. Nilai e atau error term adalah nilai unsur gangguan atau kesalahan pengganggu. Munculnya error term dalam persamaann ekonometrika merupakan suatu penegasan bahwa sebenarnya banyak sekali variabel bebas yang mempengaruhi variabel terikat. Interpretasi dari hasil regresi pengaruh belanja modal pemerintah daerah, investasi PMDN, dan investasi PMA terhadap pertumbuhan ekonomi kabupaten/kota di Provinsi NTB tahun 2014-2018 adalah sebagai berikut :

\section{Pengaruh Belanja Modal Pemerintah} Daerah Terhadap Pertumbuhan Ekonomi. Berdasarkan hasil analisis regresi yang telah dilakukan dengan menggunakan model fixed effect, menunjukkan bahwa variabel belanja modal (X1) secara individu berpengaruh positif dan signifikan dengan koefisien regresi dari variabel sebesar 0.010881 dan nilai probability sebesar 0.0017 terhadap pertumbuhan ekonomi kabupaten/kota di Provinsi NTB. Jika nilai probability dibandingkan dengan tingkat signifikansi yang digunakan dalam penelitian ini $(\alpha=0.05)$, maka terbukti bahwa nilai probability lebih kecil dari tingkat signifikan yang digunakan $(0.0017<$ 0.05). Artinya, jika realisasi belanja modal naik 1 rupiah maka pertumbuhan ekonomi kabupaten/kota di Provinsi NTB naik 0.010881 rupiah.

Belanja modal merupakan bagian dari anggaran pemerintah daerah dalam upaya menciptakan pembentukan modal di daerah yang bertujuan untuk menambah aset tetap di daerah. Hasil ini sesuai dengan teori Harrod-Domar yang menyatakan bahwa syarat untuk mencapai kondisi ekonomi yang mantap adalah 
dengan pembentukan modal dalam negara yang bersangkutan.

Belanja modal yang dilakukan oleh pemerintah daerah seperti pembangunan dan perbaikan sektor pendidikan, kesehatan, transportasi membuat masyarakat menikmati manfaat dari pembangunan daerahnya. Investasi yang dilakukan pemerintah melalui belanja modal berkontribusi pada perekonomian regional. Dengan tersedianya infrastruktur yang baik diharapkan dapat menciptakan efisiensi dan efektifitas di berbagai sektor, produktivitas masyarakat diharapkan menjadi semakin tinggi dan padagilirannya terjadi peningkatan pertumbuhan ekonomi.

Hasil penelitian ini didukung oleh temuan Daniar (2016) dan Rizky, dkk (2006) yang menyatakan bahwa belanja modal mempunyai pengaruh yang positif dan signifikan terhadap pertumbuhan ekonomi. Hal ini berarti bahwa semakin tinggi jumlah belanja modal suatu daerah maka akan meningkatkan pertumbuhan ekonomi. Komposisi belanja modal dalam peningkatan bidang sarana dan prasarana publik, investasi pemerintah juga meliputi perbaikan fasilitas pendidikan, kesehatan, dan sarana penunjang lainnya. Pembentukan modal tersebut didefinisikan secara luas sehingga mencakup semua pengeluaran yang sifatnya meningkatkan produktifitas, yang pada akhirnya meningkatkan pertumbuhan ekonomi.

\section{Pengaruh Investasi PMDN Terhadap}

\section{Pertumbuhan Ekonomi.}

Berdasarkan hasil analisis regresi yang telah dilakukan dengan menggunakan model fixed effect, menunjukkan bahwa variabel investasi PMDN (X2) secara individu berpengaruh positif dan tidak signifikan dengan koefisien regresi dari variabel sebesar 0.000523 dan nilai probability sebesar 0.0595 terhadap pertumbuhan ekonomi kabupaten/kota di Provinsi NTB. Jika nilai probability dibandingkan dengan tingkat signifikansi yang digunakan dalam penelitian ini $(\alpha=$ 0.05), maka terbukti bahwa nilai probability lebih besar dari tingkat signifikan yang digunakan $(0.0595<0.05)$. Artinya, investasi PMDN tidak berpengaruh sugnifikan terhadap pertumbuhan ekonomi kabupaten/kota di Provinsi NTB.

Hasil penelitian ini tidak sesuai dengan penelitian Prasetyo (2011), Syahrani (2011), dan Rizky (2016) yang menyatakan bahwa investasi PMDN berpengaruh dan signifikan terhadap pertumbuhan ekonomi. Ketidak sesuaian antara hasil penelitian ini dengan penelitian terdahulu 
tersebut disebabkan karena dalam penelitian ini realisasi investasi PMDN di kabupaten/kota di provinsi NTB dalam kurun waktu 2014-2018 tidak merata. Jika melihat data yang ada, dalam kurun waktu 2014-2018 beberapa kabupaten/kota pada tahun tertentu seperti Kabupaten Lombok Timur tahun 2015, Kabupaten Dompu pada tahun 2016, Kabupaten Bima pada tahun 2016, Kabupaten Sumbawa Barat pada tahun 2014, dan Kota Bima dari tahun 2014 sampai dengan 2017 tidak terdapat investasi PMDN. Selain itu, investasi PMDN bukan merupakan satu-satunya faktor yang berperan besar dalam peningkatan pertumbuhan ekonomi di provinsi NTB, hal ini dapat dilihat pada tahun 2018, realisasi investasi PMDN tahun 2018 meningkat sebesar Rp. 2,422,705,962,358 dari tahun sebelumnya namun PDRB menurun sebesar Rp. 4,257,486,000 dari tahun sebelumnya, sehingga terjadi pertumbuhan ekonomi yang negarif di provinsi NTB untuk tahun 2018. Hal ini menunjukkan bahwa walaupun terjadi peningkatan pada investasi PMDN tetapi itu tidak memberikan pengaruh yang signifikan terhadap pertumbuhan ekonomi. Faktor lain yang memiliki peranan penting dalam pertumbuhan ekonomi seperti teknologi dan tenaga kerja. Hasil penelitian ini sesuai dengan penelitian Astuti (2018) yang menyatakan bahwa investasi PMDN berpengaruh tidak signifikan terhadap pertumbuhan ekonomi..

\section{Pengaruh Investasi PMA Terhadap Pertumbuhan Ekonomi}

Berdasarkan hasil analisis regresi yang telah dilakukan dengan menggunakan model fixed effect, menunjukkan bahwa variabel investasi PMA (X3) secara individu berpengaruh positif dan signifikan dengan koefisien regresi dari variabel sebesar 0.001903 dan nilai probability sebesar 0.0000 terhadap pertumbuhan ekonomi kabupaten/kota di Provinsi NTB. Jika nilai probability dibandingkan dengan tingkat signifikansi yang digunakan dalam penelitian ini $(\alpha=0.05)$, maka terbukti bahwa nilai probability lebih kecil dari tingkat signifikan yang digunakan $(0.0000<$ 0.05). Artinya, jika investasi PMA naik 1 rupiah maka pertumbuhan ekonomi kabupaten/kota di Provinsi NTB naik 0.001903 rupiah.

Hasil ini sesuai dengan teori Harrod-Domar yang menyatakan bahwa investasi merupakan kunci di dalam proses pertumbuhan ekonomi dan untuk menumbuhkan suatu perekonomian diperlukan investasi sebagai tambahan stok modal. Dalam Arsyad (2010 : 229), manfaat investasi asing atau penanaman 
modal asing bagi negara sedang berkembang, antara lain : untuk menciptakan lapangan kerja; proses ahli teknologi dan ketrampilan yang bermanfaat; dan menjadi sumber tabungan atau devisa. Degan adanya penanaman modal asing dapat menciptakan lapanan kerja sehingga dapat menggurangi pengangguran, selain itu dengan adanya investasi asing akan mendapatkan keterampilan baru bagi negara sedang berkembang. Penanaman modal asing juga merupakan sumber tabungan kerena dengan adanya investor asing yang menanamkan modalnya maka pertumbuhan ekonomi akan meningkat.

Hasil penelitian ini didukung oleh temuan Rizky, dkk (2006) yang menyatakan bahwa investasi PMA mempunyai pengaruh yang positif dan signifikan terhadap pertumbuhan ekonomi. Hal ini berarti bahwa semakin tinggi jumlah investasi PMA suatu daerah maka akan meningkatkan pertumbuhan ekonomi.

\section{Pengaruh Belanja Modal, Investasi PMDN,} dan Investasi PMA Secara Simultan Terhadap Pertumbuhan Ekonomi.

Berdasarkan hasil estimasi diperoleh bahwa nilai F-statistik sebesar 53.56730 dengan probability sebesar $0.00000<0.05$, hal ini menunjukkan bahwa belanja modal, investasi PMDN, dan investasi PMA berpengaruh secara bersama-sama terhadap pertumbuhan ekonomi kabupaten/kota di Provinsi NTB tahun 2014-2018.

Hasil penelitian ini sesuai dengan teori Harrod-Domar yang menyatakan bahwa untuk menumbuhkan suatu perekonomian diperlukan pembentukan modal sebagai tambahan stok modal. Setiap perekonomian dapat menyisihkan suatu proporsi tertentu dari pendapatan nasionalnya jika hanya untuk menganti barang-barang modal (gedung, peralatan, material) yang rusak. Namun demikian untuk menumbuhkan perekonomian tersebut, diperlukan investasi-investasi baru sebagai stok penambah modal. Hasil penelitian ini didukung oleh temuan Rizky, dkk (2006) yang menyatakan bahwa penanaman modal asing, penanaman modal dalam negeri, dan belanja modal secara bersama-sama berpengaruh signifikan terhadap pertumbuhan ekonomi.

\section{KESIMPULAN DAN SARAN}

\section{Kesimpulan}

Berdasarkan analisis yang telah dilakukan, maka dapat diperoleh kesimpulan sebagai berikut :

1. Pengaruh Belanja Modal, Investasi PMDN, dan Investasi PMA Secara Parsial 
Terhadap Pertumbuhan Ekonomi

Kabupaten/Kota Di Provinsi NTB.

a. Variabel belanja modal berpengaruh signifikan terhadap pertumbuhan ekonomi kabupaten/kota di Provinsi NTB. Hal ini berarti bahwa kenaikan belanja modal pemerintah daerah mampu mendorong pertumbuhan ekonomi ke arah yang positif.

b. Variabel investasi PMDN berpengaruh tidak signifikan terhadap pertumbuhan ekonomi kabupaten/kota di Provinsi NTB. Artinya, investasi PMDN tidak berpengaruh secara langsung terhadap pertumbuhan ekonomi kabupaten/kota di Provinsi NTB dalam kurun waktu 2014-2018.

c. Variabel investasi PMA berpengaruh signifikan terhadap pertumbuhan ekonomi kabupaten/kota di Provinsi NTB. Hal ini berarti bahwa kenaikan investasi PMA mampu mendorong pertumbuhan ekonomi ke arah yang positif.

2.Variabel belanja modal, investasi PMDN, dan investasi PMA secara bersama-sama berpengaruh signifikan terhadap variabel pertumbuhan ekonomi kabupaten/kota di Provinsi NTB

\section{Saran}

Dari hasil penelitian yang diperoleh maka dapat diajukan beberapa saran sebagai berikut :

1. Belanja modal merupakan salah satu upaya pemerintah daerah untuk meningkatkan pertumbuhan ekonomi, sehingga pengelolaan dan penggunaannya harus maksimal agar mendorong perekonomian di daerah tersebut.

2. Pemerintah daerah diharapkan mampu menarik minat investor untuk melakukan investasi. Oleh karena itu, perlu diupayakan iklim investasi yang kondusif, seperti menyederhanakan proses perizinan serta meningkatkan kualitas sumber daya manusia agar dapat mengimbangi kemajuan teknologi dan perkembangan globalisasi, sehingga diharapkan investasi dapat semakin meningkat dan mendorong pertumbuhan ekonomi. Selain itu, perlu adannya aparat penegak hukum untuk memberikan jaminan keamanan dalam berinvestasi, serta pemerintah diharapkan terus mensosialisasikan dan mempromosikan potensi dan dampak investasi bagi masyarakat. 


\section{DAFTAR PUSTAKA}

Anonim. NTB Raih Penghargaan Indonesia Attractiveness Award 2019. https://www.suarantb.com/ntb/2019/07/273587/NTB.Raih.Penghargaan.Indone sia.Attractiveness.Award.2019/, diakses pada tanggal 20 Oktober 2019.

Anonim. Undang-Undang Nomor 33 Tahun 2004 Tentang Perimbangan Keuangan Antara Pemerintah Pusat Dan Daerah.

Anonim. Undang-Undang Nomor 25 Tahun 2007 Tentang Penanaman Modal. Anonim. Undang-Undang Nomor 23 Tahun 2014 Tentang Pemerintah Daerah.

Anonim. Undang-Undang Republik Indonesia Nomor 18 Tahun 2006 Tentang Anggaran Pendapatan Dan Belanja Negara Tahun 2007

Anonim. Peraturan Pemerintah Nomor 12 Tahun 2019 Tentang Pengelolaan Keuangan Daerah

Abdullah, Syukriy dan Darwanis Sari. 2016. Pengaruh Perubahan Anggaran Pendapatan Asli Daerah, Perubahan Anggaran Dana Bagi Hasil, dan Perubahan Anggaran Sisa Lebih Perhitungan Anggaran Terhadap Perubahan Anggaran Belanja Tidak Langsung (Studi Pada Pemerintah Kabupaten/Kota Di Aceh). Jurnal Magister Akuntansi Vol 5 No 2 Mei 2016. Pascasarjana Universitas Syiah Kuala.

Adisasmita, Rahardjo. 2013. Teori-teori Pembangunan Ekonomi. Yogyakarta: Graha Ilmu.

Afdal, Fuad. 2018. Pengararuh Investasi Asing Langsung, Penanaman Modal Dalam Negeri, dan Tenaga Kerja Terhadap Produk Domestik Bruto Pada 33 Provinsi Di Seleuruh Indonesia. Jurnal ilmiah mahasiswa FEB jurusan ilmu ekonomi Universitas Brawijaya.

Arikunto, S. 2006. Metodelogi Penelitian. Yogyakarta: Bina Aksara

Arsyad, Lincolin. 2004. Ekonomi Pembangunan Edisi Ke Empat. Yogyakarta: Bagian Penerbitan Sekolah Tinggi Ilmu Ekonomi YKPN.

2010. Ekonomi Pembangunan, edisi 5. Yogyakarta: UPP STIM YKPN.

Astuti, Puspasari, W. 2018. Analisis Pengaruh Investasi Terhadap Pertumbuhan Ekonomi (studi pada 33 provinsi di Indonesia). (Skripsi yang dipublikasikan, Fakultas Ekonomi dan Bisnis Universitas Brawijaya).

Boediono. 1992. Teori Pertumbuhan Ekonomi, Seri Sinopsis Pengantar Ilmu Ekonomi. Yogyakarta: BPFE. 
Daniar,Elysa. 2016. Pengaruh Belanja Modal Dan Tenaga Kerja Terserap Terhadap Produk Domestik Regional Bruto (PDRB) Kabupaten/Kota Di Provinsi Jawa Timur. (Skripsi yang dipublikasikan, Fakultas Ekonomi Universitas Airlangga.

Deliarnov. 1995. Pengantar Ekonomi Makro. Jakarta: III Press.

Dumairy. 1996. Perekonomian Indonesia. Jakarta: Erlangga.

Gujarati, D.N. 2012. Dasar-Dasar Ekonometrika, Terjemahan Mangunsong, R.C. Buku 2 Edisi 5. Jakarta: Salemba Empat.

Hakim, Lukman. 2013. Pengaruh Belanja Modal Terhadap Pertumbuhan Ekonomi (Studi Kasus Kabupaten Dan Kota Di Pulau Jawa Dan Bali). Jurnal ilmiah mahasiswa FEB Universitas Brawijaya. Vol 1 No. 1.

Halim, Abdul. 2004. Akuntansi Keuangan Daerah. Jakarta: Salemba Empat.

Handayani, Tri. 2011. Faktor-Faktor Yang Mempengaruhi Pertumbuhan Ekonomi Di Indonesia Periode 1999-2008. (Skripsi yang dipublikasikan, Fakultas Ekonomi universitas pembangunan nasional "veteran" Yogyakarta).

Hermawati, Wulandari. 2018. Pengaruh Belanja Modal Terhadap Pertumbuhan Ekonomi Pada Kabupaten/Kota Di Provinsi Kalimantan Utara. (TAPM yang dipublikasikan, Program Pascasarjana Universitas Terbuka Jakarta).

Jhingan, M.L. 2003. Ekonomi Pembangunan dan Perekonomian. Jakarta: PT. Raya GrafindoPersada.

2012. Ekonomi Pembangunan dan Perencanaan. Jakarta: PT. Raya GrafindoPersada.

Kuncoro, Mudrajad. 2007. Metode Kuantitatif Teori Dan Aplikasi Untuk Bisnis Dan Ekonomi Edisi Ketiga. Yogyakarta: Penerbit: UPP STIM YKPN. 2011. Metode Kuantitatif . Yogyakarta: YKPN, Sekolah Tinggi IImu Manajemen.

Mankiw, N Gregori. 2003. Teori Makroekonomi Edisi Kelima, Terjemahan. Jakarta: Erlangga. 2006. Teori Makro Ekonomi Terjemahan. Jakarta: PT. Gramedia Pustaka Utama.

Nazir, Moh. 1998. Metode Penelitian. Jakarta: Rineka Cipta 2011. Metode Penelitian. Bogor: Ghalia Indonesia.

Nordbaus D, William dan Samuelson A, Paul. 1993. Mikroekonomi Edisi Keempat Belas. Jakarta: Erlangga. 
Norlita, Vela. 2018. Pengaruh Investasi, Tenaga Kerja, dan Infrastruktur Terhadap Pertumbuhan Ekonomi Di Pulau Jawa Tahun 2006-2015. (Skripsi yang dipublikasikan, Fakultas Ekonomi Universitas Negeri Yogyakarta).

Rahardja, Pratama dan Mandala M. 2004. Teori Ekonomi Makro Suatu Pengantar Edisi Kedua. Jakarta: Lembaga Penerbit FE UI.

2008. Teori Ekonomi Makro Suatu Pengantar Edisi Keempat. Jakarta: Lembaga Penerbit FE UI.

Rizky, Reza .2016. Pengaruh Penanaman Modal Asing, Penanaman Modal Dalam Negeri Dan Belanja Modal Terhadap Pertumbuhan Ekonomi Provinsi Di Indonesia .Jurnal ilmiah mahasiswa Fakultas Ekonomi Universitas Negeri Malang . Vol. 8 No. 1.

Romer, P.M. 1986. Increasing Returns and Long Run Growth. Journal of Long Political Economy. Vol. 94, pp. 1002-34.

Rustiono, Deddy. 2008. Analisis Pengaruh Investasi, Tenaga Kerja, dan Pengeluaran Pemerintah Terhadap Pertumbuhan Ekonomi Di Provinsi Jawa Tengah. (Tesis yang dipublikasikan Fakultas Ekonopmi Universitas Diponegoro Semarang).

Salim dan Budi Sutrisno. 2008. Hukum Investasi di Indonesia. Jakarta: Grafindo Persada.

Sari, Mutia dkk. 2015. Pengaruh Investasi, Tenaga Kerja Dan Pengeluaran Pemerintah Terhadap Pertumbuhan Ekonomi Di Indonesia. (Skripsi yang dipublikasikan, Fakultas Ekonomi UNSYIAH Darussalam-Banda Aceh).

Sukirno, Sadono. 1985. Ekonomi Pembangunan, Proses, Masalah, dan Dasar Kebijaksanaan. Jakarta: LPFE UI.

Susanti, Hera dkk. 2000. Indikator-indikator Makroekonomi. Jakarta: Erlangga.

Supanca, Ida BR. 2006. Kerangka Hukum dan Kebijakan Investasi Langsung Di Indonesia. Bogor: Ghalia Indonesia.

Syaiful. 2006. Pengertian dan Perlakuan Akuntansi Belanja Barang dan Belanja Modal Dalam Kaidah Akuntansi Pemerintah. Artikel.

Syaharani, Febrina, R. 2011. Pengaruh Penanaman Modal Dalam Negeri, Penanaman Modal Asing, dan Utang Luar Negeri Terhadap Pertumbuhan Ekonomi Di Indonesia Periode 1985-2009. (Skripsi yang dipublikasikan, Fakultas Ilmu Ekonomi dan Bisnis Universitas Islam Negeri Syarif Hidayatullah).

Todaro, P.Michael. 2006. Pembangunan Ekonomi Jilid 1 Edisi Kesembilan. Jakarta: Unit Penerbit dan Percetakan Erlangga Jakarta. 
Prasetyo, Eko. 2011. Analisis Pengaruh Penanaman Modal Dalam Negeri (PMDN), Penanaman Modal Asing (PMA), Tenaga Kerja, dan Ekspor Terhadap Pertumbuhan Ekonomi Di Jawa Tengah Periode Tahun 1985-2009. (Skripsi yang dipublikasikan, Fakultas Ekonomi Universitas Negeri Semarang).

Widarjono, Agus. 2009. Ekonometrika Pengantar dan Aplikasinya : Edisi Ketiga. Yogyakarta: Ekonesia.

Zhang, Tao and Heng-fuZou. 1998. Fiscal Decentralization, Public Spending, And Economic Growth In China. China. Journal Of Public Economic, 67:221-240. 